\title{
Human-Nature Ecological Interaction of African Traditional Community in Chinua Achebe's Things Fall Apart (Literary Ecology Approach in Literature)
}

\author{
Hadiyanto Hadiyanto ${ }^{1}$, Wiwik Sundari ${ }^{2}$, Atrinawati Atrinawati ${ }^{3}$ \\ ${ }^{1}$ English Department, Faculty of Humanities, Diponegoro University, Semarang, Indonesia \\ ${ }^{2}$ English Department, Faculty of Humanities, Diponegoro University, Semarang, Indonesia \\ ${ }^{3}$ English Department, Faculty of Humanities, Diponegoro University, Semarang, Indonesia
}

\begin{abstract}
This research paper discusses the ecological interaction between humans and nature in African traditional Ibo tribe community as described in a literary work of Chinua Achebe's Things Fall Apart by using literary ecology approach in literature. The result of the research indicates that African traditional tribe community has a good, intense interaction and has a harmonious life with nature, for instances, they learn to mingle familiarly with dry season, rainy season, and harmattan season for a successful farming method and harvest of yam, they also learn to interact very well with various kinds of vegetations such as bamboo, kola nut, banana leaves, grasses, roots, barks of trees to fulfil their life necessities, and they learn to have knowledge for an effective interaction and good usage of animals for ritual and meal, especially goat and locust. African traditional community also has a strong commitment to keep the harmonious relationship with nature by maintaining a life balance with nature including vegetation and animal, to enjoy living in happiness with nature by warmly welcoming various seasons, such as rainy season, dry season, and the cold dusty harmattan season, and to maintain natural resources friendly and wisely in clearing the new land for planting staple-food plants and other supporting plants sufficiently.
\end{abstract}

\section{Background of the Research}

The harmonious life between humans and nature has been ecologically established from time to time anywhere throughout the world. It begins long in the past since humans undeniably depend on their lives in nature. They have no power to cope with the real power of nature, having been often shown in everyday life. Such emerging nature phenomena lead humans to be amazingly fascinated not merely with the power of nature but also with beauty, goodness, and blessing having been numerously given by nature. If humans can live along, adapt happily, and learn appropriately from nature around, they will undoubtedly be able to use knowledge of various natural phenomena for the quality betterment of humans' lives in many aspects. Humans' knowledge of vegetation and animals, which are parts of nature, will also 
give a lot of advantages and prosperities for the fulfillment of humans' life necessities. Humans and nature interaction are ecologically inseparable.

The term ecology can be defined as the science that explores a mutual relationship between humans and the physical environment in all areas of cultural production [1]. Ecologically, the harmonious interaction between humans and nature is also reflected in many literary works that explore friendly measures and decisive roles of humans in interacting with nature. In this present time, human-nature representation is widely used to analyze literary works emphasizing human behavior in preserving a green environment. Human as God's creature has a lot of solid points and eminences compared to other creatures. Humans' minds and thoughts can protect, preserve, and prosper nature for the long-term goodness of living together with other people. Humans, ecologically, take responsibility for restoring nature devastation and preventing the upcoming natural disaster due to humans' faults and crimes in exploiting nature such as flash floods, landslides, long dry season, etc. Ecological phenomena of human-nature interaction that emphasize harmony and balance of natural elements are reflected in one of the literary works entitled "Things Fall Apart" written by African author Chinua Achebe. Things fall apart is a novel portraying the life of a traditional African community with a green natural environment and abundance of natural resources that attract white-skinned people to the land of the native Ibo tribe in Africa.

\section{Method of Research}

\subsection{Research Approach}

Based on the background of the research that reveals human-nature ecological interaction phenomena of the traditional African community in a literary work of Chinua Achebe's Things Fall Apart, the researchers use literary ecology approach in literature or better known as the ecocriticism approach to analyze such related phenomena in the novel. The literary ecology approach in literature or ecocriticism approach emphasizes a study to understand the problems of ecology from a literary perspective or, conversely, how to understand literary work from an ecology perspective [2]. The relationship between ecology and literature becomes the object of literary ecology. Literary ecology learns how humans adapt and interact with nature.

\subsection{Method of Data Collection}

Method of data collection is conducted to analyze Chinua Achebe's Things Fall Apart by using library research. Library research is research conducted in a working room or a library of a researcher to obtain data and information related to the object of the research through books or any other audio-visual appliances [3]. The researchers use Chinua Achebe's Things Fall Apart novel as primary research data. In contrast, secondary data are taken from any other related written sources functioned as supporting data, such as reference textbooks, journals, articles, and so on.

\section{Discussion}

\subsection{Learning Changing Seasons from Nature Cycles}


As reflected in Chinua Achebe's Things Fall Apart, the traditional African community learns to recognize the changing seasons properly as a result of natural cycles, such as the rainy season and the dry season. The change of the seasons is learned and identified by the Ibo tribe community as a knowledge concept of nature for farming methods, especially planting yams. With the knowledge concept they learn from nature, the traditional African community plants the seeds of yams in the right moment and expects to have a successful harvest of yams for everyday staple food. Most native African people have reaped great success as yam farmers. However, some local village folks fail for yam harvest due to the inaccurate calculation in anticipating the changing season related to when to plant and when to harvest. As a traditional farmer society, they plant the seeds of yams and other plants a single day right after the rain falls down the dried farming land, and they harvest the yams after the dry season comes.For instance, the novel's main character, Okonkwe, learns to recognize the natural phenomena and the kinds of seasons knowledge inherited by his ancestors to be a successful farmer. As a man raised in the Ibo land of Africa, the continent with the large Sahara Desert, Okonkwo is very familiar with the dusty wind season. The season that is so dried and cold for the African Ibo community is better known as harmattan season. This harmattan season blows from the Sahara Desert to the west coast of Africa and emerges between November and March. The so-wet and so-cold dusty wind season signify the nearest upcoming rainy season. Conversely, the so-dried and so-hot dusty wind season signalizes the upcoming dry season in the Ibo land of Africa. The local traditional community's knowledge about harmattan season can be viewed in this quotation: "And it was not too hot either, because the cold and dry harmattan wind was blowing down from the north. Some years the harmattan was very severe, and a dense haze hung on the atmosphere." [4]. With the mastery of the knowledge concept of the accurate season, Okonkwo and the local African community of the Ibo tribe work hard as yam farmers to prosper their families.

\subsection{Learning the Advantages of Vegetations}

The traditional African Community also learns to have a knowledge concept mastery on various kinds of vegetations around. Vegetation knowledge is essential for the local people to help make their daily lives easier, such as eating, drinking, sleeping, traditional medication, etc. Bamboo trees, for example, is functioned to make various bamboo beds for sleep, palm trees for lamp oil, cola nut for guest food serving, yams for staple food, banana tree for dessert consumption, and banana leaf for traditional food wraps.

Classic knowledge about leaves, grasses, bushes, plant roots, and bark of trees are used for traditional medical treatment. This can be viewed when Okonkwo tries to heal Enzima, the daughter of his second wife, lying on the bed feverishly and shiveringly beside a big fireplace. Okonkwo's daughter suffers from iba or fever as quoted; "It is iba," said Okonkwo as he took his machete and went into the bush to collect the leaves and grasses and barks of trees that went into making the medicine for iba [4]. Another quotation also reflects that Okonkwo returned from the bush carrying on his left shoulder a large bundle of grasses and leaves, roots, and barks of medicinal trees and shrubs [4]. Based on both quotations, it can be inferred that through the representation of Okonkwo, the traditional African Community recognizes and masters the use of parts of plants effectively and mixes them for sickness medication. Every time a minor child or family member gets sick, even more than fever, Okonkwo uses parts of plants effectively to make sedative medicines using slicing parts of the plants and to mix water as necessary. He boils them in a big pot until the medicine concoction boils. The liquid medicine concoction made from plant ingredients is subsequently brewed and given to the child or another member of the family who is suffering from iba or fever to drink. 


\subsection{Learning the Advantages of Animals}

Knowledge Knowledge of certain animals, especially goats, is also learned by the traditional African community. A goat is a particular animal for the African people because of its functions and advantages. Local people realize that it needs the knowledge to be learned to breed such a herbivore animal successfully. Goat in traditional Africa is primarily functioned for offering rituals to the ancestor spirits to be in peacefulness and happiness. The second function of the goat is to make goat leather floor mats, the simple fine mats that can be folded and taken anywhere. With simple knowledge, the process of leather mat making is by peeling the goat leather and drying it until its bad smell vanishes. The third function of the goat is as the raw material of leather bag making; the goatskin bag is used to keep and carry the foods, drinking horns, locusts, etc. This goatskin bag has become popular among Ibo tribe society every day, as reflected in the quotation; "Okonkwo was sitting on a goatskin already eating his first wife's meal. Everybody thanked Okonkwo, and the neighbors brought out their drinking horns from the goatskin bag they carried." [4]. Based on the quotation, it can be analyzed that the traditional African community has been able to learn animals as part of nature to support their daily activities.

Another popular, rare animal that has been learned by African Ibo tribe society is the locust. This locust animal, widely consumed by many local folks, flies around the Ibo land periodically. Thousands of locusts fly to be scattered under the sky of Ibo land in the cold harmattan season after the yams harvest. Those thousands of locusts fly away to look for food by eating up the grass in the field. Locusts are consumed as additional food for the Ibo people as quoted; "For although locusts had not visited Umuofia for many years, everybody knew by instinct that they were outstanding to eat." [4]. This quotation shows that they know about tasty locusts eaten. The appearance of locusts is every seven years consecutively, then the locusts disappear in the next seven years, and they appear again for the upcoming seven years, and so on. The abundance of locusts in harvest season causes children, teenagers, and adults of the Ibo tribe to catch and make food. By baking and drying the locusts under the sunray, local traditional people then eat the locusts with palm oil.

\subsection{Keeping the Harmonious Relationship with Nature}

African traditional community has excellent ecological interaction with nature by keeping and living a harmonious life in the geographical environment around. This can be viewed based on the mutual commitment of Ibo tribe society to maintain a life balance with nature, including vegetation and animal. Social life and mutual advantage concept between humans and nature becomes the basis to act of Ibo tribe community to treat, protect, and preserve the surrounding natural environment. For example, Okonkwo shows his attitude with great concern for the trees planted. As quoted below, he gets very angry with his wife's careless attitudes that cause the banana tree he likes best to be gradually withered for its leaf.

\section{"Who killed this banana tree?" he asked. \\ A hush fell on the compound immediately. \\ "Who killed this tree? Or are you all deaf and dumb?"}

As a matter of fact the tree was very much alive. Okonkwo's second wife had merely cut a few leaves off it to wrap some food, and she said so. Without further argument Okonkwo gave her a sound beating and left her and her only daughter weeping. [4]

Based on the quotation, it can be analyzed that even though plant leaves can function for life necessities, it does not mean African Ibo tribe society has to exploit vegetation massively without any responsibilities to preserve nature. Okonkwo's anger reflects his concern with 
the protection and preservation of the nature of vegetation around. The quotation can be critically meant that Okonkwo, as the representation of the traditional African community, has a considerable concern about taking care of a banana tree. Moreover, his concern and care towards green forest surrounding the native villages.

\subsection{Enjoying Living in Happiness with Nature}

Aside from adults and older adults, the children of the traditional African community show their happiness to enjoy living with various seasons from the rainy season, dry season, and the cold, dusty harmattan season. When rainy seasons fall accompanied by the lights of thunder, Ibo tribe children take a seat peacefully around the big cooking fireplace with their mother telling a folktale or sitting with their father in front of a fireplace to warm their body in obi traditional house by baking the corns and enjoying eating the baked corns as reflected in the quotation below.

And so nature was not interfered with in the middle of the rainy season. Sometimes it poured down in such thick sheets of water that earth and sky seemed merged in one gray wetness. It was then uncertain whether the low rumbling of Amadiora's thunder came from above or below. At such times, in each of the countless thatched huts of Umuofia, children sat around their mother's cooking fire telling stories, or with their father in his obi warming themselves from a long fire, roasting and eating maize. [4]

Enjoying living peacefully with the natural endowment of vegetation, animals, as well as any kinds of seasons is also seen from young men's happiness in welcoming the ice rainfall from the sky that they consider as a God gift, "water peanuts of heaven." They show real happiness by enjoying eating and drinking the frozen snow from the sky that means adaptive attitudes of the African Ibo tribe community in living a happy life with nature around. Their happiness with whatever happens in the land of Africa is the reflection of sincere acceptance towards all natural phenomena in the sky and earth and their influence on Ibo tribe society's daily life. Life happiness for the grace of rainfall for children and young people of Ibo tribe society is quoted below.

When the rain finally came, it was in large, solid drops of frozen water which the people called "the nuts of the water of heaven." They were hard and painful on the body as they fell, yet young people ran about happily picking up the cold nuts and throwing them into their mouths to melt.

The earth quickly came to life and the birds in the forests fluttered around and chirped merrily. A vague scent of life and green vegetation was diffused in the air. As the rain began to fall more soberly and smaller liquid drops, children sought for shelter, and all were happy, refreshed, and thankful. [4]

The quotation implies that anything falls from the sky and comes out of the earth; they do not feel restless, grumble, and blame for nature and different seasons. Little birds chirping happily with the rainy season fertilizing all green vegetation expands happiness and freshness for every Ibo tribe people. Expression of gratitude to God's gift from the sky, the earth, and seasons represents their happy, harmonious life with nature around. 


\subsection{Maintaining Natural Resources Friendly and Wisely}

African traditional community has a significant commitment to maintaining the natural resources friendly, wisely, and effectively. They use natural resources to support life necessities such as planting yams and other living plants. The land clearing is carefully and sufficiently carried out by all members of the Ibo tribe society and their families. Meanwhile, the land cultivated for farming is not acquired by cutting down forests illegally or illegal logging in a particular area of Ibo tribe society. It is a result of cutting down bushes and grasses in unproductive lands. The new land clearing is usually executed while approaching the dry season's end. As quoted below, the rainy season will immediately come by cutting down bushes and grasses, drying them, and burning them.

After the Week of Peace every man and his family began to clear the bush to make new farms. The cut bush was left dry and fire was then set to it. As the smoke rose into the sky kites appeared from different directions and hovered over the burning field in silent valediction. The rainy season was approaching when they would go away until the dry season returned.

Okonkwo spent the next few days preparing his seed-yams. He looked at each yam carefully to see whether it was good for sowing. [4]

Based on the quotation, it can be concluded that the new land clearing will possibly be carried out if it is planted with vegetations used as sources of staple foods or other supporting plants. The land clearing is not intended for children's playgrounds, cattle and goat pens, and traditional obi houses. Such a decision is made with the realization by the Ibo tribe community that preservation of nature ecology will always be maintained from time to time, from generation to the next generation, as a manifestation of the relationship between local African folks and the nature around. With such a solid commitment to a relationship with nature, significant advantages of natural goodness will return to prosper the traditional African community.

\section{Conclusion}

African traditional community, as reflected in Chinua Achebe's Things Fall Apart, has an intense interaction and a harmonious life with nature; for instance, they learn to mingle familiarly with the dry season, rainy season, and harmattan season for a successful farming method and harvest of yam, they also use and interact very well with various kinds of vegetations such as bamboo, kola nut, banana leaves, grasses, roots, barks of trees to fulfill their life necessities, and they know to effectively interact and make good use of animals for ritual and meal, especially goat and locust. In addition to that, African traditional Ibo tribe society also has a solid commitment to keep the harmonious relationship with nature by maintaining a life balance with nature including vegetation and animal, to enjoy living in happiness with nature by warmly welcoming various seasons, such as rainy season, dry season, and the cold, dusty harmattan season, and to maintain natural resources friendly and wisely in clearing the new land for planting staple food plants and other supporting plants sufficiently.

The research on human-nature ecological interaction will undoubtedly give a lot of positive thought contributions to the global community to understand better the ways to learn such local wisdom, live a harmonious and peaceful life, and keep on preserving nature with self-awareness. With this research implication, the global community is encouraged not to exploit and destroy the surrounding nature for the sake of their interest or other interests of certain related parties. This research will hopefully broaden the scope of knowledge to study 
literary works, either novel, novella, short story, drama, or poetry, from the perspective of literary ecology or ecocriticism.

\section{References}

1. Achebe Achebe, Chinua. Things Fall Apart. Everyman's Library, David Campbell Publishers Ltd., London, (1958).

2. Clark, Timothy. The Value of Ecocriticism. Cambridge University Press, Cambridge, United Kingdom, 2019.

3. Dattaray, Debashree, et.al. Ecocriticism and Environment: Rethinking Literature and Culture. Primus Books, India, (2018).

4. Endraswara, Suwardi. Metodologi Penelitian Ekologi Sastra: Konsep, Langkah, dan Penerapan. CAPS (Center for Academic Publishing Service), Yogyakarta, (2016).

5. Garrard, Greg. Ecocriticism. Second Edition. Routledge, London and New York, (2012).

6. Glotfelty, Cheryll, et.al. The Ecocriticism Reader-Landmarks in Literary Ecology. The University of Georgia Press, Georgia, (1996).

7. Rignall, John, et.al. Ecology and The Literature of British Left. Ashgate Publishing Limited, Wey Court East, England, (2012).

8. Schiliephake, Christhopher. Ecocriticism, Ecology, and The Cultures of Antiquity. Lexington Books, Lanham, Maryland, (2017).

9. Semi, Atar. Metode Penelitian Sastra. Angkasa Publishing, Bandung, (1993).

10. Waldron, Karen E, et.al. Toward A Literary Ecology. The Scarcrow Press Inc., Plymouth, United Kingdom, (2013). 